\title{
Species composition and plant performance of mixed seagrass beds along a siltation gradient at Cape Bolinao, The Philippines
}

\author{
Steffen S. Bach ${ }^{1}$, Jens Borum ${ }^{1, *}$, Miquel D. Fortes ${ }^{2}$, Carlos M. Duarte $^{3}$ \\ ${ }^{1}$ Freshwater Biological Laboratory, University of Copenhagen, Helsingersgade 51, DK-3400 Hillerød, Denmark \\ ${ }^{2}$ Marine Science Institute, College of Science, University of The Philippines, Diliman, 1101 Quezon City, The Philippines \\ ${ }^{3}$ Centro de Estudios Avanzados de Blanes, CSIC, Camino de Santa Barbara, E-17300 Blanes, Girona, Spain
}

\begin{abstract}
The response of mixed Southeast Asian seagrass beds to siltation was analyzed based on field data, a transplantation experiment and experimental manipulation of light availability in seagrass populations along a silt gradient at Cape Bolinao, The Philippines. Seagrass species diversity, shoot density and depth penetration declined with increasing amounts of suspended material and increasing water column light attenuation along the silt gradient. The seagrass species could be ranked according to decreasing tolerance to siltation as: Enhalus acoroides > Cymodocea serrulata > Halodule uninervis $>$ Thalassia hemprichii > Halophila ovalis > Cymodocea rotundata > Syringodium isoetifolium. A gradual decline in shoot density and depth penetration of the different species along the silt gradient suggested that changes in the vertical light attenuation coefficient in the water column, primarily caused by differences in suspended inorganic solids, was the most important factor affecting seagrass performance. However, inconsistency among the species in response to increasing water depth, artificial shading and transplantation indicated that other factors, such as siltation-derived changes in sediment conditions, contribute to the sequential loss of seagrass species along the silt gradient.
\end{abstract}

KEY WORDS: Seagrasses - Siltation - Eutrophication · Transplantation · Artificial shading

\section{INTRODUCTION}

Seagrass beds are threatened worldwide by human disturbances such as land reclamation or changes in land use (Fortes 1988, 1995, Short \& Wyllie-Echeverria 1996). The rapid progression of coastal development, near- and offshore mining, agricultural land use and deforestation has led to increasing silt load and eutrophication. This has caused dramatic changes in seagrass growth conditions and decline of species composition and areal cover of seagrass beds in temperate and tropical waters (Orth \& Moore 1983, Cambridge \& McComb 1984, Onuf 1994, Terrados et al. 1998).

Siltation may affect seagrass growth by reducing light availability through increased water column light attenuation (Vermaat et al. 1997), increased sedimen-

-Addressee for correspondence. E-mail: borum@ibm.net tation and burial (Duarte et al. 1997) and, possibly, by changing sediment conditions (Terrados et al. 1998). The relationships between light conditions and photosynthesis, growth and depth distribution of temperate seagrasses clearly document that light availability is the prime regulating factor for plant performance (e.g. Bulthuis 1983, Dennison 1987, Olesen 1996). In tropical seas, which are most often characterized by clear waters and high incoming irradiance throughout the year, shallow seagrass stands seem to be limited largely by the availability of nutrients (e.g. Agawin et al. 1996), while their maximum depth penetration is controlled by light availability (Duarte 1991).

Silt from rivers and land reduces underwater light penetration by increasing both light absorption and scattering (Kirk 1983, Onuf 1994). Increased nutrient loading, which is also associated with siltation (Malmer \& Grip 1994), may reduce light availability to seagrass meadows by favoring growth of phytoplankton, macro- 
algae and epiphytes (Sand-Jensen \& Borum 1991, Duarte 1995). Restricted seagrass abundance will, in turn, decrease the physical protection of surface sediments provided by the plants (Fonseca et al. 1982), enhance sediment resuspension (Bulthuis et al. 1984) and, thereby, deteriorate the light climate for the remaining seagrass stands.

Mixed seagrass communities in Southeast Asia comprise up to 13 species, ranging in size from the small Halophila spp. to the large Enhalus acoroides (Brouns 1987, Fortes 1995, Terrados et al. 1998). Interspecific competition for space, light and nutrients among species is likely intense, and even small changes in light climate car therefore be expected to affect species composition and depth penetration of the mixed seagrass beds. The differential ability of seagrasses to change architecture and accommodate to changing light availability may, however, be decisive for the variable siltation tolerance among seagrass species (e.g. Vermaat et al, 1997).

The aim of this project was to describe the changes in species composition, depth distribution and growth performance of seagrasses along a siltation gradient

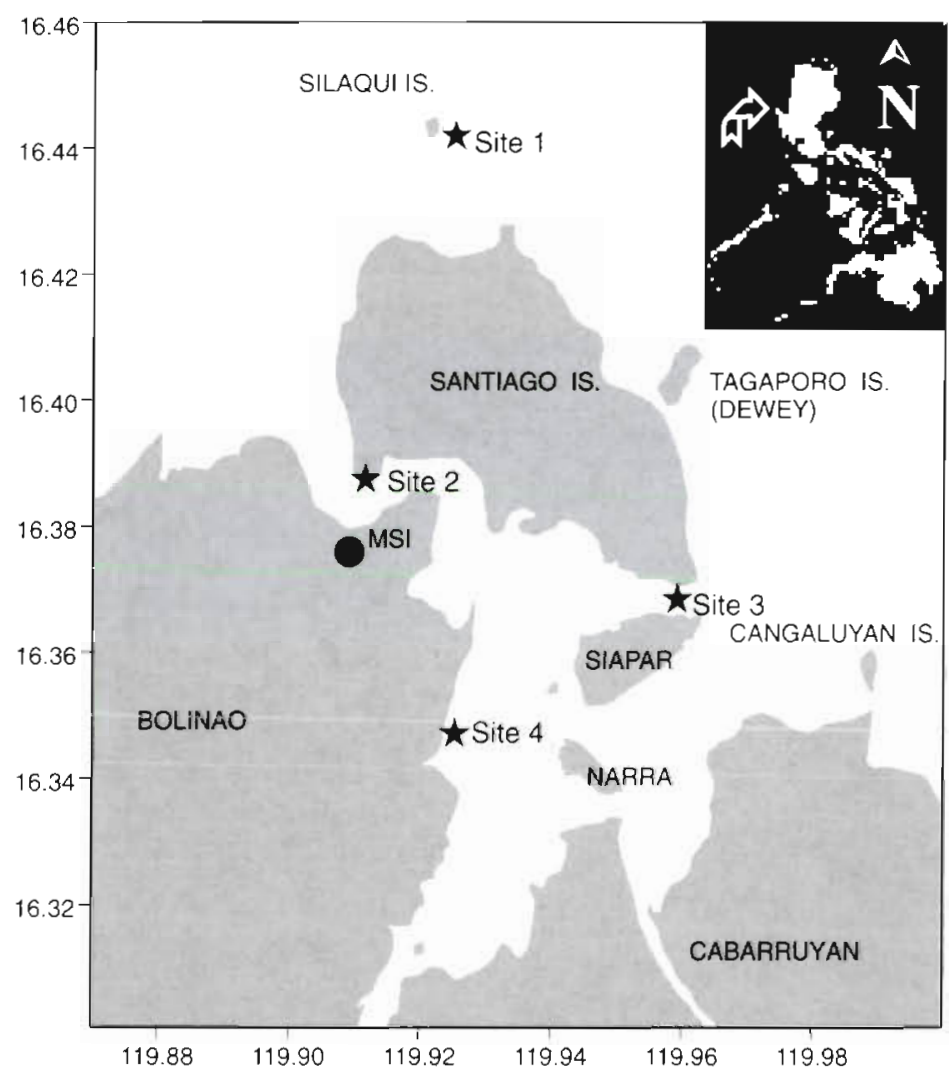

Fig. 1 Study area at Cape Bolinao, The Philippines. Sampling sites are marked with stars. Site 1: Silaqui Island; Site 2: Binaballian Loob; Site 3: PIslatan; Site 4: Santa Barbara; and MSI: Marine Science Institute field station and to experimentally test the role of light climate in these changes. We hypothesized the deterioration of underwater light climate to be the most important factor forcing changes in species composition of seagrass beds with increasing siltation. We expected, therefore, that a loss of seagrass species along the siltation gradient should parallel the loss of species with increasing water depth at unperturbed sites, and that plant responses to experimental manipulation of light availability should reflect their differential ability to survive siltation. We measured suspended solids and water column light attenuation along with changes in seagrass species composition and leaf growth rates along the siltation gradient, and we made in situ manipulations of light climate by artificial shading and cross-site transplantation of seagrass plots.

\section{MATERIALS AND METHODS}

Study area. The study was performed at the Santiago Island reef system at Cape Bolinao, Luzon, The Philippines $\left(16^{\circ} 26^{\prime} \mathrm{N}, 119^{\circ} 55^{\prime} \mathrm{E}\right)$. The area, located in the northwestern part of the Pangasinan province, is surrounded by the most extensive reefs in the Lingayen Gulf (McManus et al. 1990). The reef barrier stretches around the Cabarruyan Island, the northern part of Santiago Island and continues further down the west coast of Cape Bolinao (Fig. 1). Within the reef barrier, the coral cover is patchy and extensive seagrass beds cover an area of approximately $25 \mathrm{~km}^{2}$ (Fortes 1995).

The mixed seagrass beds in the undisturbed areas north of Santiago Island include $7 \mathrm{com}$ mon species: Enhalus acoroides (L.f.) Royle, Thalassia hemprichii (Ehrenb.) Aschers., $C y$ modocea serrulata (R. Br.) Aschers. \& Magnus, Cymodocea rotundata Ehrenberg. \& Hempr. ex Aschers., Halodule uninervis (Forssk.) Aschers., Syringodium isoetifolium (Aschers.) Dandy. and Halophila ovalis (R. Br.) Hook f. Four study sites were selected along a silt gradient. A reference site (Site 1) adjacent to Silaqui Island contained all species and was assumed to be minimally affected by human activity (Fig. 1). Site 2 (Binaballian Loob), Site 3 (Pislatan) and Site 4 (Santa Barbara) were located along the gradient of increasing siltation, from north to south. Only sparse and patchy seagrass stands of $E$. acoroides were found in the more silted areas south of Santa Barbara.

All measurements were conducted during the monsoon period from June to August 1995. Maximum semi-diurnal tidal range was 
$0.75 \mathrm{~m}$ at all sites. Average monthly precipitation was high, being 220, 520 and $410 \mathrm{~mm}$ for June, July and August. Incident irradiance was measured at the Observatory in Laoag, Ilocos Norte $\left(18^{\circ} 11^{\prime} \mathrm{N}\right.$, $\left.120^{\circ} 32^{\prime} \mathrm{E}\right)$, while data on temperature and precipitation were received from Dagupan City Station (16 $03^{\circ} \mathrm{N}, 120^{\circ} 20^{\prime} \mathrm{E}$ ).

Light and suspended matter. Depth profiles of downwelling underwater photosynthetic active radiation (PAR; 400 to $700 \mathrm{~nm}$ ) were obtained weekly at a deep station (more than $4 \mathrm{~m}$ ) and a shallow station ( $1 \mathrm{~m}$ ) for each of the 4 sites using a submersible quantum sensor (LI-192SA, 2 $\pi$ ). The average light attenuation coefficient $\left(K_{d}\right)$ was calculated from the standard light attenuation equation of Lambert-Beer (Kirk 1983).

Duplicate water samples were collected weekly in the middle of the water column at each site using dark 41 plastic containers. Concentrations of water column chlorophyll a (chl a) were determined by filtering 1 to 21 of seawater through Whatman GF/C filters. The filters were folded, wrapped into aluminum foil and stored at $-7^{\circ} \mathrm{C}$. Chl a was analyzed spectrophotometrically after $24 \mathrm{~h}$ of extraction in $10 \mathrm{ml}$ of $90 \%$ acetone (Parsons et al. 1984).

Suspended organic and inorganic solids were measured by filtering 0.5 to 21 of seawater onto pre-ignited and pre-weighed Whatman GF/C filters. Wet weight of filters plus solids was determined for later correction of salt content. The filters were dried at $80^{\circ} \mathrm{C}$ for $24 \mathrm{~h}$ and reweighed to determine dry weight. Particulate organic matter (POM) was determined as weight loss on ignition at $550^{\circ} \mathrm{C}$ for $8 \mathrm{~h}$ and particulate inorganic matter (PIM) as the ash content remaining. The contribution of salt to PIM was estimated from the salinity of the water contained in wet filters.

A Pearsons Product Moment correlation analysis and multiple linear regression were applied to analyze relationships among water column light attenuation and concentrations of chl a, POM and PIM. The relative importance of these variables for light attenuation was determined by path analysis (Sokal \& Rohlf 1995). The data were in-transformed prior to statistical analysis to meet parametric assumptions.

Seagrass density and species composition. Shoot density of seagrasses at the different sites was estimated at the beginning of the study period using a $0.5 \times 0.5 \mathrm{~m}$ frame divided into 25 quadrants of $0.01 \mathrm{~m}^{2}$. All species were identified and counted in 10 quadrants in each of 5 frames at depths of $0.0,0.5,1.0,2.0$ and $3.0 \mathrm{~m}$ relative to the level of mean low tide (MLT). Shoot density of the large Enhalus acoroides was estimated by counting all the shoots within 20 frames.

Seagrass growth. During 3 periods (starting dates: June 25, July 10 and July 25) leaf growth of the dominant seagrass species in the region. Thalassia hempri- chii, Cymodocea serrulata and Enhalus acoroides (Terrados et al. 1998), was measured along a depth gradient at Site $1(0.5,1.0,2.0$ and $3.0 \mathrm{~m})$ and at $0.5 \mathrm{~m}$ depth at all 4 sites along the siltation gradient. Leaf growth was determined using a leaf marking technique (Zieman \& Wetzel 1980). A minimum of 15 shoots were tagged with collared plastic markers, and holes were punched with a syringe needle through the leaf bundle just above the leaf sheaths. The marked shoots were harvested after a period of $14 \mathrm{~d}$ and leaf growth was measured as the leaf area produced between the marker and the holes on every leaf. Young leaves without holes were recorded as newly emerged. Total leaf area was estimated by measuring leaf length and width, and the relative leaf growth rate was calculated as $\mathrm{cm}^{2}$ leaf produced per $\mathrm{cm}^{2}$ leaf per day. Two-way ANOVA and Fisher's LSD procedure were used to test for differences in growth rates among sites, depths, and sampling periods.

Shading experiment. Shading screens were established over a mixed seagrass bed at $1.0 \mathrm{~m}$ depth adjacent to Site 1 at Silaqui Island (Fig. 1). The screens, which were made of $1.5 \times 1.5 \mathrm{~m}$ PVC-pipe frames with 3 layers of fine meshed, black nylon net, were buoyed approximately $70 \mathrm{~cm}$ above the sea floor. The relative light reduction of PAR by the shading screens was 75 to $80 \%$, simulating light conditions during maximum turbidity in shallow seagrass beds at the most silted site (Site 4). Leaf growth was assessed in 3 control and 3 shaded plots during 2 periods: from 6 to 14 July and from 2 to 13 August. The shading screens were cleaned every second day to remove algae and detritus. Twenty shoots of Thalassia hemprichii, Cymodocea serrulata and $C$. rotundata, positioned in the center of the plots, were marked as described above. Upon harvest, leaf growth was calculated as absolute growth $\left(\mathrm{cm}^{2}\right.$ shoot $\left.^{-1} \mathrm{~d}^{-1}\right)$, and the plastochrone interval (PI; $\mathrm{d}$ [new leaf] ${ }^{-1}$ shoot $^{-1}$ ) was calculated from the appearance of new unmarked leaves. In addition to growth, shoot size and specific leaf weight were measured. Because there were no differences in average temperature or daily photon flux density during the 2 periods, and because plant responses were identical, data from the 2 experiments were pooled for the analysis. As a consequence, 6 observations of both shaded and control plants were compared using a t-test.

Transplantation experiment. A transplantation experiment across the siltation gradient was conducted from June 20 to August 30. Plant turfs were collected at $0.5 \mathrm{~m}$ depth from the undisturbed mixed seagrass population at Site 1 , using a $30 \mathrm{~cm}$ diameter steel corer, and were placed in $35 \times 35 \times 45 \mathrm{~cm}$ containers. The turfs contained all species except Enhalus acoroides, which was deliberately avoided because of its large shoots. At each of the study sites, 6 containers were 
Table 1. Mean concentration, standard error $(n=16)$ and range (in parentheses) of suspended particulate inorganic matter (PIM), particulate organic matter (POM), phytoplankton biomass (chl a) and mean light attenuation coefficient $\left(K_{d}\right)$ in the water column at 4 localities along the siltation gradient at Cape Bolinao. a to d: sites with different letters have significantly different values ( $p<$ 0.05 ) according to a Tukey HSD test

\begin{tabular}{|c|c|c|c|c|}
\hline Site & $\underset{\left(\mathrm{mg} \mathrm{l}^{-1}\right)}{\text { PIM }}$ & $\begin{array}{c}\text { POM } \\
\left(\mathrm{mg} \mathrm{l}^{-1}\right)\end{array}$ & $\begin{array}{c}\mathrm{Chl} a \\
\left(\mu \mathrm{g} \mathrm{l}^{-1}\right)\end{array}$ & $\begin{array}{c}K_{d} \\
\left(\mathrm{~m}^{-1}\right)\end{array}$ \\
\hline 1. Silaqui Island & $\begin{array}{l}3.5 \pm 0.57 a \\
(1.5-6.1)\end{array}$ & $\begin{array}{l}2.6 \pm 0.3 \mathrm{a} \\
(1.3-3.5)\end{array}$ & $\begin{array}{l}0.34 \pm 0.04 \mathrm{a} \\
(0.11-0.66)\end{array}$ & $\begin{array}{l}0.31 \pm 0.03 a \\
(0.17-0.52)\end{array}$ \\
\hline 2, Binaballian Loob & $\begin{array}{l}4.8 \pm 0.5 b \\
(2.74-8.27)\end{array}$ & $\begin{array}{l}3.5 \pm 0.4 \mathrm{ab} \\
(1.95-5.75)\end{array}$ & $\begin{array}{l}0.80 \pm 0.10 b \\
(0.33-1.71)\end{array}$ & $\begin{array}{l}0.43 \pm 0.06 b \\
(0.20-1.04)\end{array}$ \\
\hline 3, Pislatan & $\begin{array}{l}4.6 \pm 0.3 b \\
(2.3-5.7)\end{array}$ & $\begin{array}{l}3.7 \pm 0.5 b \\
(1.7-7.9)\end{array}$ & $\begin{array}{l}1.14 \pm 0.16 b \\
(0.22-2.31)\end{array}$ & $\begin{array}{l}0.61 \pm 0.04 \mathrm{c} \\
(0.33-1.06)\end{array}$ \\
\hline 4, Santa Barbara & $\begin{array}{l}8.2 \pm 1.1 \mathrm{C} \\
(4.0-11.5)\end{array}$ & $\begin{array}{l}4.3 \pm 0.3 b \\
(3.4-7.5)\end{array}$ & $\begin{array}{l}2.04 \pm 0.28 c \\
(0.62-4.42)\end{array}$ & $\begin{array}{l}0.91 \pm 0.08 \mathrm{~d} \\
(0.47-1.60)\end{array}$ \\
\hline
\end{tabular}

strong intercorrelation among all 3 predictor variables $(\mathrm{r}=0.50$ to 0.71 , $p<0.001$ ). We, therefore, separated the correlation coefficients into direct contributions made by the individual variables and indirect contributions using path analysis (Sokal \& Rohlf 1995). The direct effect of each variable (standard correlation coefficients) on light attenuation was calculated by multiple regression with standardized values. By including all 3 variables in 1 model the squared regression coefficient $\left(\mathrm{I}^{2}\right)$ increased to 0.60 ( $p<0.001$, ANOVA, Table 2 ). For both PIM and chl a the direct effect constituted approximately $50 \%$ of the total correlation coefficient, while for

positioned at a water depth of $0.5 \mathrm{~m}$ (relative to MLT) and at a distance of $1 \mathrm{~m}$ apart. Units planted at Site 1 were used to control for the effect of the transplantation procedure itself. Shoot density of all species was counted initially and at $14 \mathrm{~d}$ intervals. The effect of transplantation on shoot density was tested using a 2-way ANOVA, with study sites and time as independent variables. Prior to statistical analysis the data were tested for normality and homogeneity of variance.

\section{RESULTS}

\section{Suspended matter and light attenuation}

The mean concentrations of suspended POM and PIM and the biomass of phytoplankton (chl a) increased from Site 1 to Site 4 (Table 1). Precipitation increased from June to August resulting in a general increase with time of suspended matter (data not shown), but the silt gradient persisted throughout the study period. Maximum concentrations of total suspended solids were $19 \mathrm{mg}$ dry wt $^{-1}$ and $4.42 \mu \mathrm{g} \mathrm{chl} \mathrm{a}$ $\mathrm{l}^{-1}$ at Site 4 in early August after heavy rainfall. The mean downwelling light attenuation coefficient varied from $0.31 \mathrm{~m}^{-1}$ at Site 1 to $0.91 \mathrm{~m}^{-1}$ at Site 4 and tended to increase during the experimental period at all 4 sites (data not shown)

The light attenuation coefficient was significantly correlated to suspended inorganic and organic solids and phytoplankton biomass (Table 2). The coefficient of determination $\left(\mathrm{r}^{2}\right)$ suggests that PIM, accounting for $56 \%$ of the total variability, was the best single predictor of light attenuation in the water column, while the concentration of POM and chl a explained 40 and $47 \%$ of the variance, respectively. There was, however, a
POM it was only $35 \%$. PIM had the highest indirect effect of the variables, accounting for about 40 and $36 \%$ of the total correlation coefficient for POM and chl $a$, respectively.

\section{Seagrass species composition, depth distribution and density}

Seagrass species composition, depth distribution and shoot density changed markedly along the silt gradient (Table 3). The number of seagrass species declined from 7 at Site 1 to 2 at Site 4 The large Enhalus acoroides and the medium-sized Cymodocea serrulata occurred at all sites, and $E$. acoroides was also recorded from shallow depths $(\leq 0.5 \mathrm{~m})$ in more silted areas south of Site 4. Halodule uninervis, Halophila ovalis and Thalassia hemprichii were absent from the most silted locality, while C. rotundata was only found at Sites 1 and 2. Syringodium isoetifolium only

Table 2. Correlation and path analysis of ln-transformed values ( $\mathrm{n}=48$ ) of the downwelling light attenuation coefficient $\left(K_{d}\right)$ and the concentration of particulate inorganic matter (PIM), organic matter (POM) and phytoplankton biomass (chl a) in the water column along the siltation gradient at Cape Bolinao. The correlation coefficients ( $r$ ) for the individual variables, which were all significant $(p<0.001)$, equal the sum of direct (italicised) and indirect effects of the path analysis. The total variation $\left(\mathrm{r}^{2}\right)$ explained by multiple regression was 0.60

\begin{tabular}{|lcccc|}
\hline & $\mathrm{r}$ & in PIM & ln POM & ln chl a \\
\hline In PIM & 0.739 & 0.359 & 0.161 & 0.229 \\
ln POM & 0.636 & 0.246 & 0.228 & 0.162 \\
ln chl a & 0.685 & 0.245 & 0.113 & 0.327 \\
\hline
\end{tabular}


Table 3. Seagrass shoot density per $\mathrm{m}^{2}$ (mean $\pm \mathrm{SE}, \mathrm{n}=10$ ) at different water depths (relative to the level at mean low tide) at 4 sites along the siltation gradient at Cape Bolinao. ( Species present at the site but at densities below those resolved in the quantitative analysis; (O) species absent

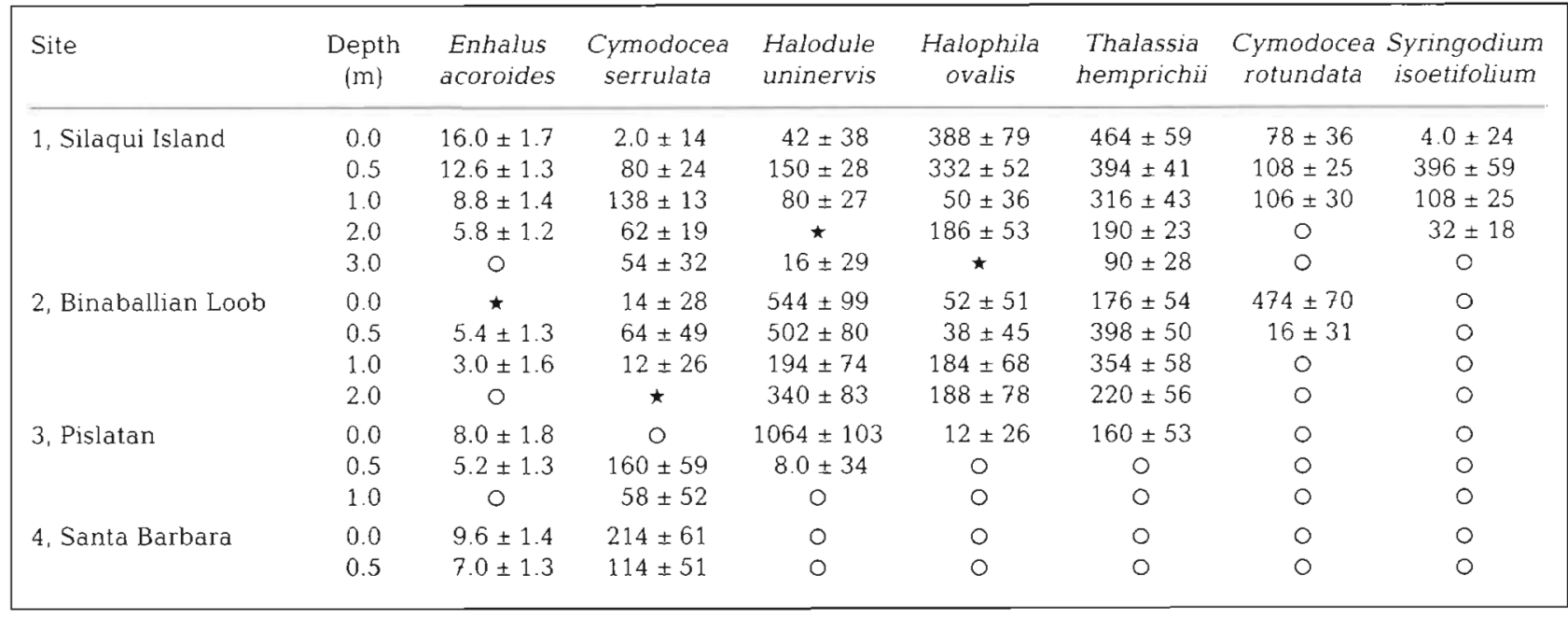

occurred at the site affected least by silt close to Silaqui Island.

The lower depth limit of all seagrass species declined systematically along the silt gradient (Table 3). Maximum depth penetration of the main plant patches was between 2 and $3 \mathrm{~m}$, but patches of Halophila ovalis and Halodule uninervis were found down to $7-9 \mathrm{~m}$ depth at Site 1 and to $4 \mathrm{~m}$ at Site 2 . Shoot density also tended to decline with increasing depth and along the silt gradient. At a depth of $0.0 \mathrm{~m}$ relative to MLT, the seagrass beds were, however, occasionally exposed to desiccation and direct sunlight during low tide, probably causing low shoot density or absence of some of the species at this depth. From the overall changes in species composition, depth penetration and shoot density along the siltation gradient the 7 seagrasses could be ranked from the most to the least persistent species as follows: Enhalus acoroides $>$ Cymodocea serrulata $>$ Halodule uninervis > Thalassia hemprichii > Halophila ovalis > Cymodocea rotundata $>$ Syringodium isoetifolium.

\section{Leaf growth along the silt gradient}

The relative leaf growth rates of Thalassia hemprichii, Cymodocea serrulata and Enhalus acoroides were measured in shallow water ( $0.5 \mathrm{~m}$ MLT) when present at the 4 stations along the silt gradient (Fig. 2). There was no systematic decrease in relative leaf growth with increasing silt load (1-way ANOVA, $p>0.05$ ). At Site $2, C$. serrulata and $T$. hemprichii actually had significantly higher growth rates $(p<0.05$, multiple range test) than at other sites, and E. acoroides tended to grow faster (not statistically significant) with increas- ing silt load. Accordingly, leaf growth of the 3 species in shallow water seemed unaffected by differences in suspended material among sites.

\section{Leaf growth versus depth and with artificial shading}

The relative leaf growth rate of Thalassia hemprichii, Cymodocea serrulata and Enhalus acoroides was measured at different depths at Site 1 to assess the effect of decreasing light availability (Fig. 3). Average light availability in percent of subsurface irradiance was $85 \%$ at $0.5 \mathrm{~m}, 73 \%$ at $1.0 \mathrm{~m}, 54 \%$ at $2.0 \mathrm{~m}$ and $38 \%$ at $3.0 \mathrm{~m}$. The leaf growth of $T$. hemprichii was significantly lower at $3.0 \mathrm{~m}$ (1-way ANOVA, p < 0.0001, multiple range test) than at more shallow sites, and also the leaf growth of E. acoroides was lower at $2.0 \mathrm{~m}$ (p $<$ 0.05). Leaf growth of $C$. serrulata did, however, not respond to increasing depth and, in general, the responses of all 3 species to increasing depth were moderate. Because there were no systematic changes in shoot size with depth for each species (data not shown), similar patterns were found for absolute and relative rates of leaf growth.

When light availability was reduced by 75 to $80 \%$ through artificial shading, absolute leaf growth rates of Thalassia hemprichii, Cymodocea serrulata and $C y$ modocea rotundata growing at $1.0 \mathrm{~m}$ depth decreased significantly ( $t$-test, $\mathrm{p}<0.05$, Fig. 4a). With declining growth rates, the shoot size of all species (not statistically significant for $C$. rotundata) tended to decline (Fig. 4b). The combined effect of reduced growth and shoot size resulted in moderate increases (not significant for C. rotundata) in leaf plastochrone intervals of 


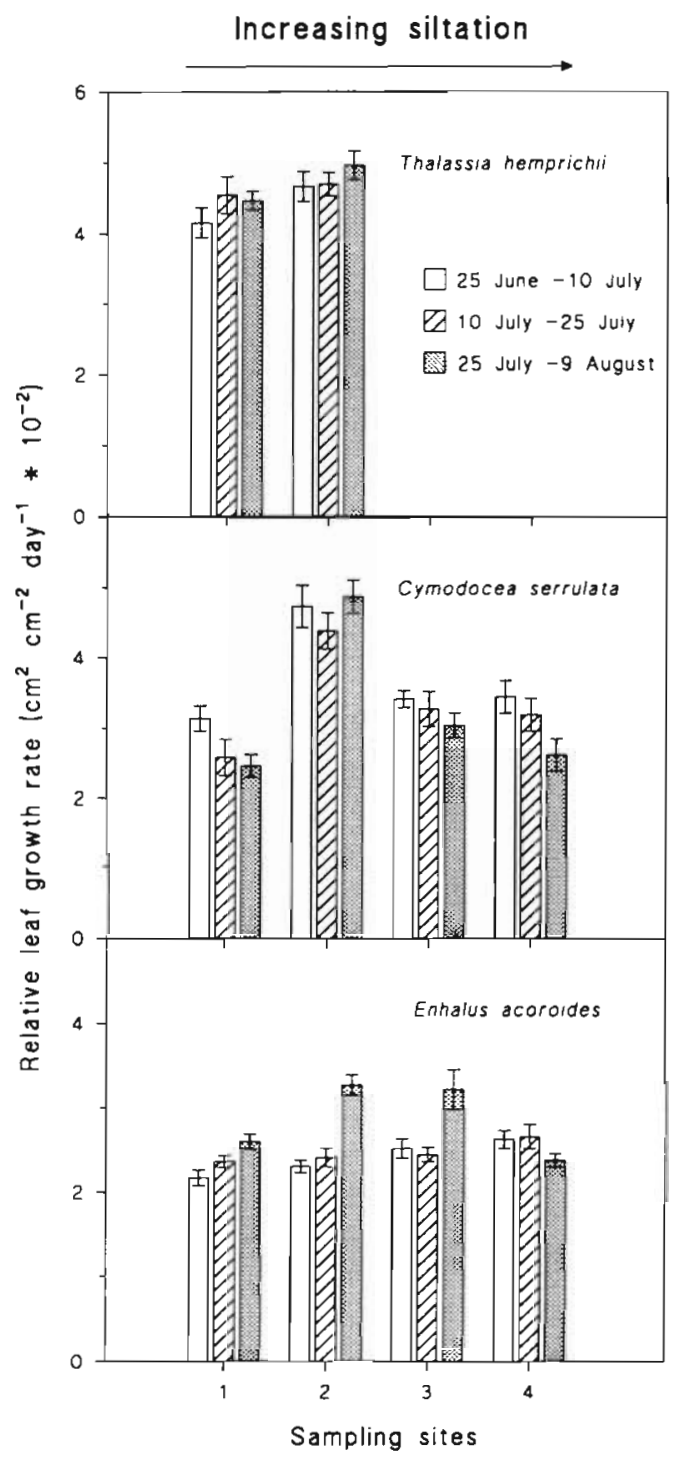

Fig. 2. Specific leaf growth of 3 larger seagrass species growing at $0.5 \mathrm{~m}$ depth along the siltation gradient at Cape Bolinao. Values are means and standard errors $(n=15)$ measured during 3 different periods

all species (Fig. 4c). T. hemprichii also responded ( $\mathrm{p}<$ 0.01 ) by a modest reduction in specific leaf weight (Fig. 4d), while no changes in specific leaf weight were observed for C. serrulata and C. rotundata.

\section{Transplantation experiment}

The survival and shoot density of all seagrass species, except Enhalus acoroides, were recorded from late June to late August in the transplanted sediment cores originally sampled at Site 1 (Figs. 5 \& 6). Light attenuation increased significantly along the silt gradient (Table 1), and the light reaching the leaf canopy of

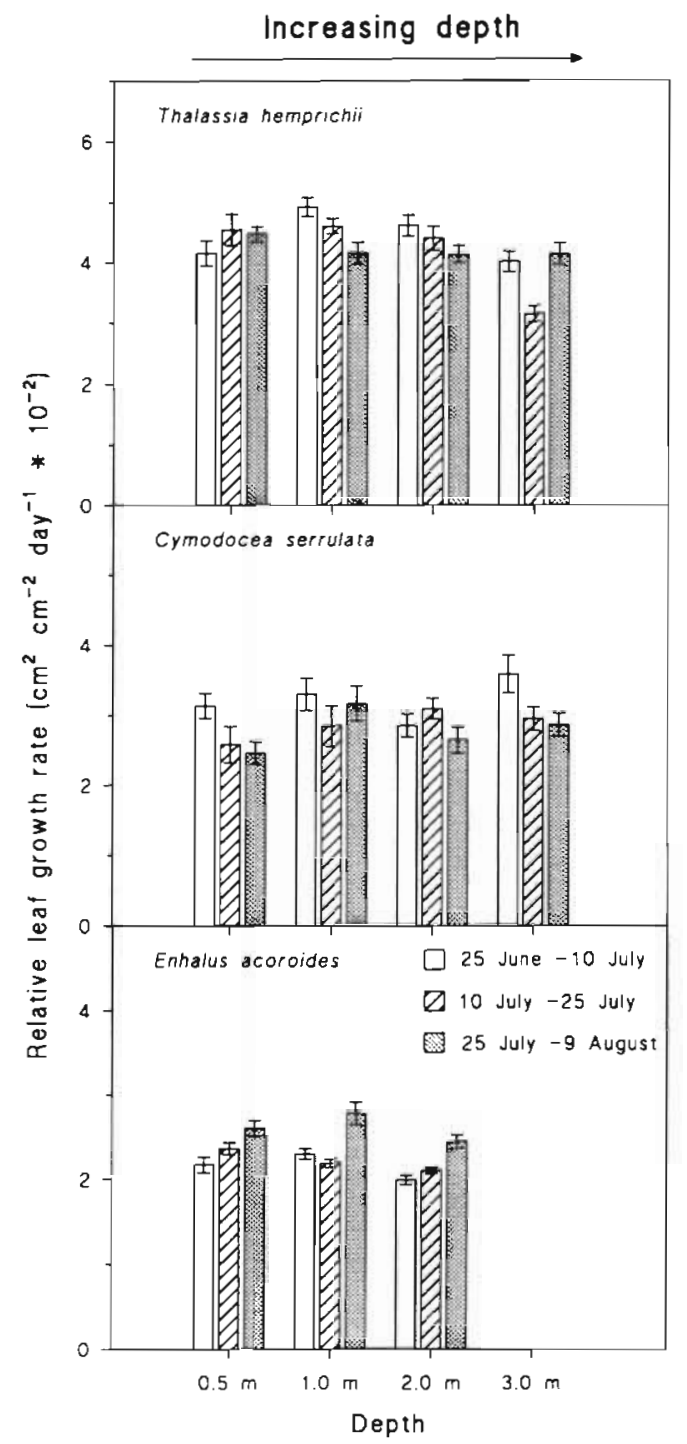

Fig. 3. Specific leaf growth versus depth of 3 larger seagrass species growing at the control site, Site 1 . Values are means and standard errors $(n=15)$ measured during 3 different periods

the transplants at $0.5 \mathrm{~m}$ depth varied from $70-80 \%$ of subsurface irradiance at Site 1 to $20-60 \%$ at Site 4 .

The transplantation process itself affected seagrass shoot density, and this effect was most evident for the dominant species, Thalassia hemprichii, the shoot density of which declined during the first month at all sites including the control site (2-way ANOVA, $\mathrm{p}<0.00001$, Fig. 5). Towards the end of the experiment the number of shoots stabilized at approximately half the initial density with no apparent differences among sites. The small Halophila ovalis exhibited the opposite response (Fig. 5). H. ovalis was initially present, though not counted, in moderate numbers in all transplant units. At the end of the experiment high densities of $H$. ovalis 

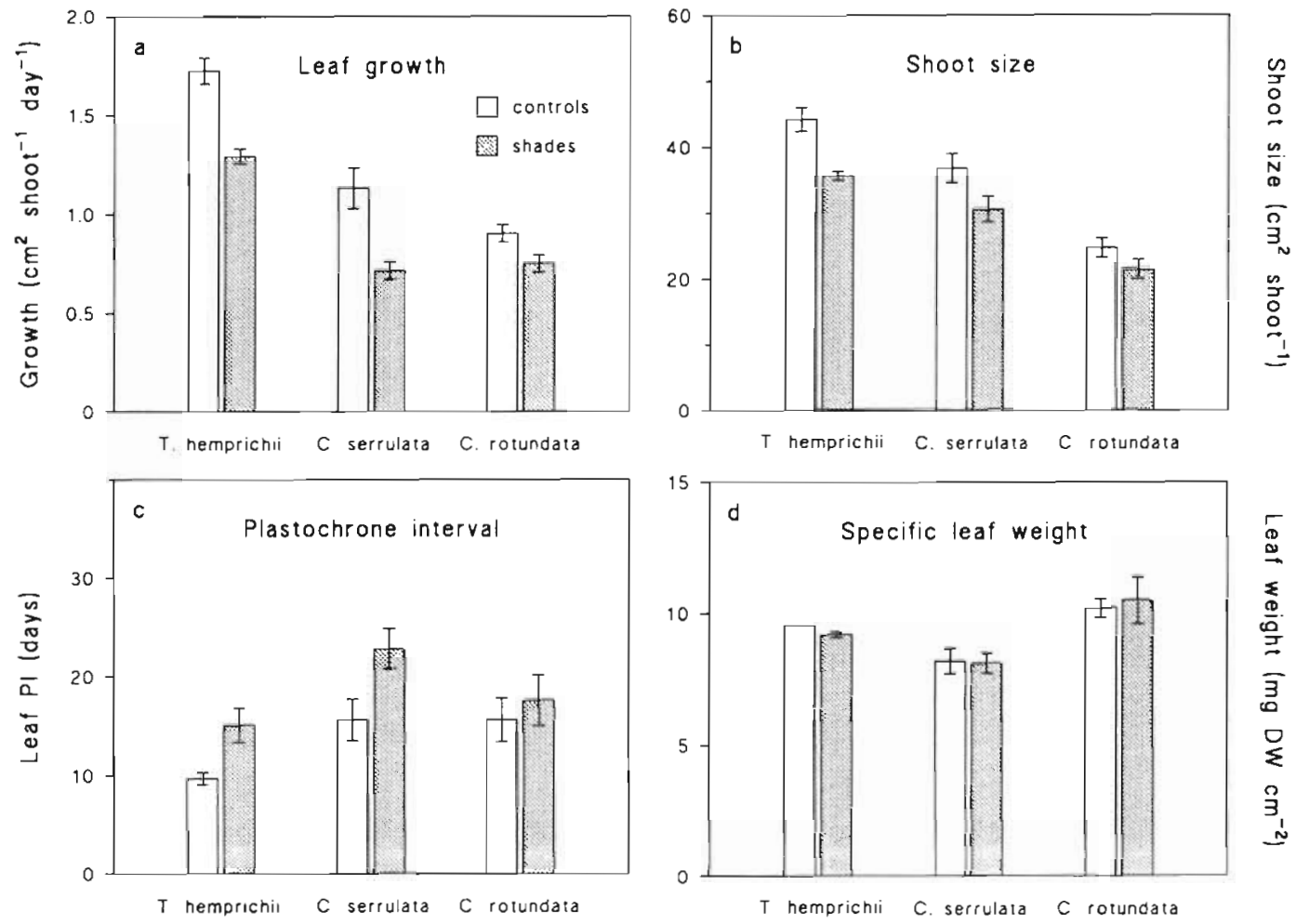

Fig. 4. Responses to artificial shading of 3 larger seagrass species growing at Site 1. (a) Leaf growth, (b) shoot size, (c) plastochrone interval (PI) and (d) specific leaf weight in control and shaded plots. Values are means and standard errors ( $\mathrm{n}$. $=6$ )

developed at the control site probably as a result of more available space due to the transplantation-induced decline of the larger species. At the end of the experiment, $H$. ovalis was found at low density at Site 2, but had totally disappeared at the more silted Sites 3 and 4 .

To properly evaluate differences among sites, it was necessary to normalize shoot densities in relation to initial densities (Fig, 6), because the initial shoot density of some seagrass species varied substantially among sites. Furthermore, only data from the last 3 sampling dates, when shoot density had equilibrated following transplantation stress (e.g. Fig. 5), were compared by using non-parametric ANOVA (Kruskal-Wallis test) with site as independent variable. By this approach, Thalassia hemprichii still did not show any differences among sites $(p>0.10)$, suggesting no major effects of siltation on the performance of this species. The abundance of Cymodocea serrulata tended to increase $(p<0.10)$, while the shoot density of Cymodocea rotundata declined $(p<0.01)$ moderately, with

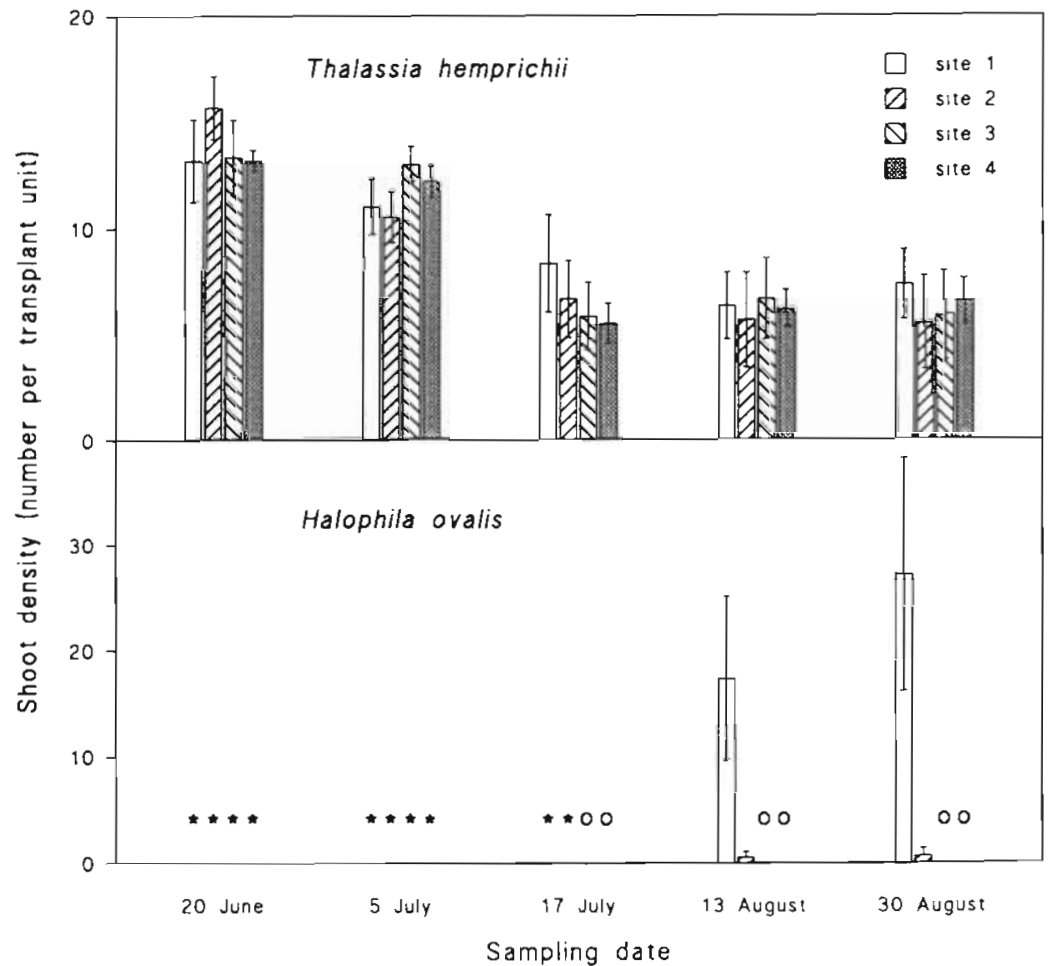

Fig. 5. Temporal changes in shoot density of Thalassia hemprichii and Halophila ovalis in units transplanted from the mixed seagrass bed at Site 1 to all 4 sites along the siltation gradient at Cape Bolinao. Values are means and standard errors $(n=6)$. On the first 3 sampling dates, presence $(\star)$ or absence (O) of $H$. ovalis was recorded, but shoot densities were not quantified 


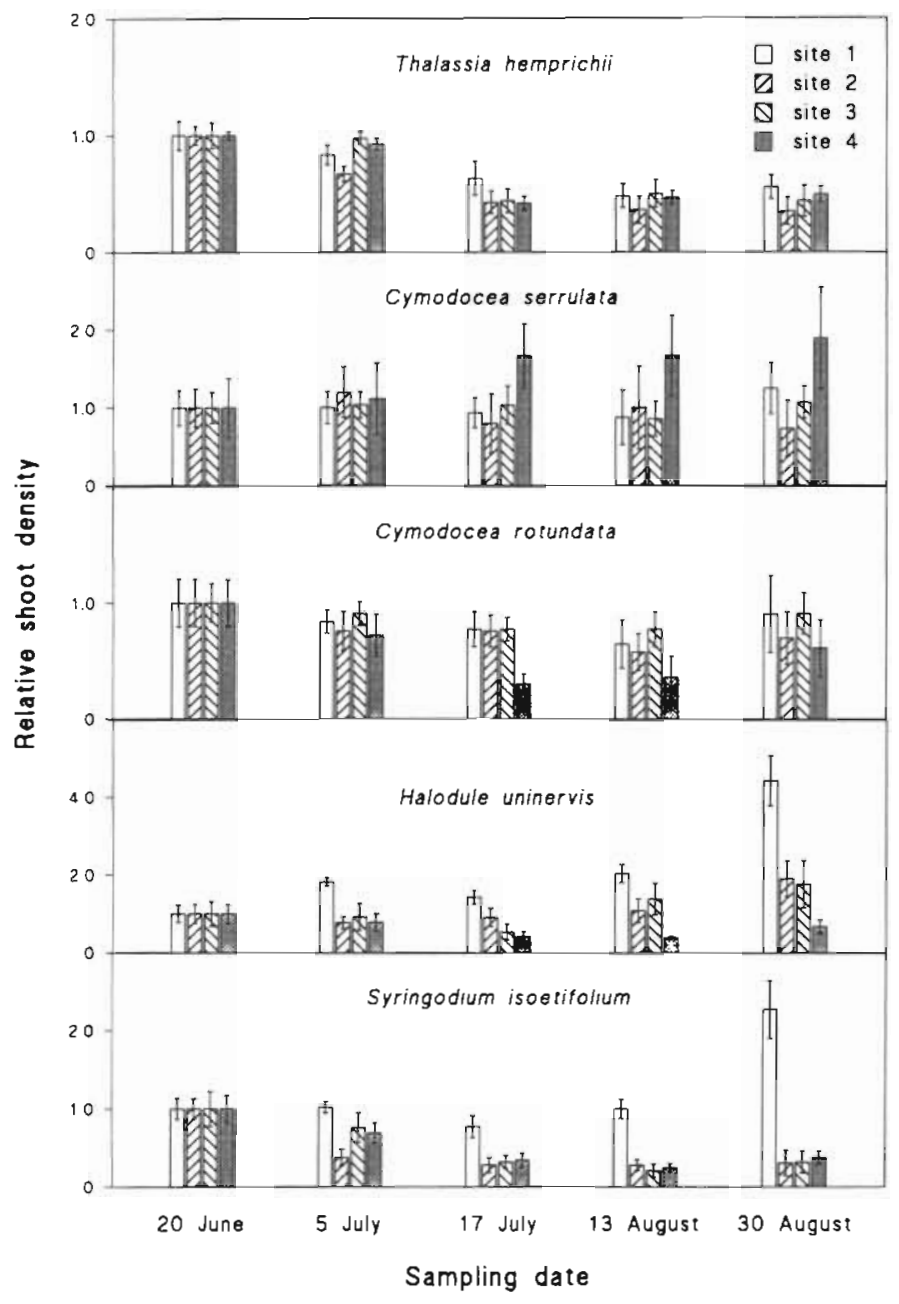

Fig. 6. Temporal changes in shoot density (relative to the initial density on 20 June) in seagrass units transplanted from the mixed seagrass bed at Site 1 to all 4 sites along the siltation gradient at Cape Bolinao. Values are means and standard errors $(n=6)$

increasing silt load. However, the small species, Halodule uninervis and especially Syringodium isoetifolium, responded strongly ( $\mathrm{p}<0.00001)$ to increasing siltation (Fig 6), but, in contrast to Halophila ovalis, both survived throughout the experiment albeit at low density at the most silted sites.

\section{DISCUSSION}

Siltation at Cape Bolinao is caused by coastal development and intensive land use (Fortes 1995) resulting in a distinct gradient of suspended particulate matter and water transparency among the study sites. Both particulate matter, in general, and phytoplankton biomass increased along the gradient, suggesting that siltation was accompanied by increased nutrient run-off from land, a coupling which is also observed with deforestation (Malmer \& Grip 1994). The 3-fold increase in the vertical light attenuation coefficient along the siltation gradient can mainly be attributed to increased concentrations of PIM along with a parallel increase in phytoplankton biomass. In addition, settled particulate matter and epiphytes on the seagrass leaves contributed to reduce light availability for the plants (Bach 1997).

The diversity and depth penetration of the mixed seagrass beds at Cape Bolinao declined systematically with increasing siltation. The seagrass species could be ranked after their tolerance to siltation as: Enhalus acoroides $>$ Cymodocea serrulata $>$ Halodule uninervis $>$ Thalassia hemprichii > Halophila ovalis > Cymodocea rotundata $>$ Syringodium isoetifolium, with $E$. acoroides being the most tolerant. The observed sequential loss of species among sites is in full accordance with that found in a broader comparison among seagrass beds along silt gradients in The Philippines and Thailand (Terrados et al. 1998), suggesting that the sequence represents a general pattern of tolerance to siltation among Southeast Asian seagrass species.

The mixed seagrass bed on the reef flat around Silaqui Island was dense and diverse, resembling other Philippine seagrass beds free from major anthropogenic perturbations (Fortes 1995). Co-existence of different seagrass species is partly based on differential exploitation of sediment resources and light (Williams 1987, Vermaat et al. 1995), but interspecific competition within the mixed beds can also be substantial (Tomasko 1992, Agawin et al. 1996). The transplant experiment showed, that if the density of one or more species was reduced, others could profit and expand. Thus, following transplantation the shoot density of Halophila ovalis, Halodule uninervis and Syringodium isoetifolium increased at the control site, probably because the density of the dominant species, Thalassia hemprichii, declined. Similar stimulation of small, fast-growing seagrasses following decline of larger species, has been observed after experimental manipulation of seagrass densities (Williams 1987) and experimental burial of a mixed seagrass bed (Duarte et al. 1997). Accordingly, environmental perturbation may affect the performance of individual seagrass species directly but also indirectly by influencing interspecific competition.

The gradual decline of seagrass depth penetration along the siltation gradient strongly supports the hypothesis that light availability was a key factor controlling changes in seagrass performance with increasing siltation. Duarte (1991) developed a general empirical relationship between seagrass depth penetration ( $Z$ in $\mathrm{m}$ ) and water column light attenuation $\left(K_{d}\right.$ in $\mathrm{m}^{-1}$ ): $\log Z=0.26-1.07 \log K_{d}$. According to this relationship 
the expected seagrass depth limits should be 5.6 (Site 1), 3.8 (Site 2), 2.8 (Site 3) and $1.6 \mathrm{~m}$ (Site 4 ) when computed from the observed mean attenuation coefficients. These estimated depths are slightly deeper but, considering the tidal range of $0.75 \mathrm{~m}$ and the possible spectral changes of the light due to the high concentrations of PIM (Kirk 1983), close to the observed depth limits of the seagrass stands at our 4 sampling sites.

The gradual decline in shoot density of individual species with depth and with increasing siltation further suggests that suspended material, light availability and seagrass performance are strongly connected. When Thalassia hemprichii, Cymodocea rotundata and Cymodocea serrulata were subjected to artificial shading at the control site, their leaf growth also responded clearly to reduced light availability. However, leaf growth of $T$. hemprichii, C. serrulata and Enhalus acoroides growing naturally along the siltation gradient did not respond to differences in light climate among sites and was only moderately affected by reduced light availability with increasing depth. These observations suggest that individual seagrass shoots are able to sustain high leaf growth rates over relatively broad ranges of light availability, and that leaf growth is only reduced when plants are exposed to major changes in light climate. The explanation may be that seagrasses growing under reduced light availability allocate a lower fraction of photosynthetic products to underground tissues (Madsen \& Sand-Jensen 1994) and formation of new shoots. As a result, shoot density declines and light availability improves for the remaining shoots because of reduced self-shading within the stands. Several studies have shown that artificial shading of seagrass stands results in declining growth rates (e.g. Bulthuis 1983, Gordon et al. 1994), but prolonged conditions of improved (Williams 1987) or reduced light availability (Ziemann et al. 1989) induce changes in shoot density and biomass rather than changes in relative growth rates.

The original hypothesis that the sequential Ioss of species along the siltation gradient would parallel the loss of species with increasing depth at the control site and the species-specific responses to transplantation was only partly fulfilled. The 2 relatively persistent species Cymodocea serrulata and Thalassia hemprichii both grew to $3 \mathrm{~m}$ depth at Site 1 and did not respond markedly to reduced light conditions in the transplant experiment. The least persistent species, Syringodium isoetifolium, disappeared at depths greater than $2 \mathrm{~m}$ at the control site and also responded strongly to transplantation. However, the species most tolerant to siltation, Enhalus acoroides, did not grow very deep at the control site but formed healthy patches in areas even more heavily influenced by siltation than our Site 4 . Furthermore, Halophila ovalis and Halodule uninervis responded strongly to transplantation, but both species grew much deeper at Site 1 than any other species, reflecting relatively low light requirements. These latter observations suggest that low tolerance of some species to siltation results from factors besides changes in water column light attenuation.

In addition to water transparency, siltation may also influence sediment grain size, resuspension and resistance to oxygen diffusion. The fine-grained material is more readily resuspended, and therefore seagrass beds in silted areas may more often experience events of partial burial, which has clear species-specific effects that parallel the sequence of species loss reported here (Duarte et al. 1997). The large Enhalus acoroides and species with high capacity of vertical rhizome growth (e.g. Cymodocea serrulata) are tolerant to siltation (Vermaat et al. 1997) and are less influenced by burial, while smaller species, such as Halodule uninervis and Syringodium isoetifolium, respond strongly to burial (Duarte et al. 1997). Seagrass species may also respond differently to changes in oxygen and redox conditions in the sediment depending on their morphology and ability to maintain root oxygen supply (Smith et al. 1988). Accordingly, the integrated response of mixed seagrass beds to siltation is likely to be caused by changes in both water column and sediment conditions, and we suggest that sediment-plant interactions should further be considered to explain patterns of seagrass distribution along gradients of anthropogenic pertubation.

Rates of siltation in Southeast Asia have increased substantially during the past $20 \mathrm{yr}$ and are among the highest in the world (Milliman \& Meade 1983, Milliman \& Syvitski 1992). The present study has confirmed that siltation has a major negative impact on the diversity and depth penetration of the highly productive seagrass beds. The results suggest that, although the effect of siltation on water column light attenuation is a key factor, changes in sediment conditions may also play an important role for seagrass performance. The negative effects of siltation on the diverse Southeast Asian seagrass beds are likely reversible, but the time scale of ecosystem recovery is virtually unknown. To be able to predict rates of recovery, more knowledge should be gained on the dynamics and transport of silt in coastal areas, seagrass requirements for sediment conditions and colonization potentials of different seagrass species.

Acknowledgements. This study was funded by the STD-III program of the Commission of the European Union (Project TS3.-CT94-0301) and by the Faculty of Natural Sciences, University of Copenhagen. Sincere thanks to Maikee Roleda, Gabriel de Guzman and Henriette Basse for assistance in field and laboratory. Contribution 1083 from the Freshwater Biological Laboratory, University of Copenhagen. 


\section{LITERATURE CITED}

Agawin NSR, Duarte CM, Fortes MD (1996) Nutrient limitation of Philippine seagrasses (Cape Boljnao, NW Philippines): in situ experimental evidence. Mar Ecol Prog Ser 138:233-243

Bach SS (1997) Havgrœessers voekst og artssammensœtning langs en siltgradient ved Kap Bolinao, Filippinerne. MSc thesis, Freshwater Biological Laboratory, University of Copenhagen

Brouns JJWM (1987) Quantitative and dynamic aspects of a mixed seagrass meadow in Papua New Guinea. Aquat Bot 29:33-47

Bulthuis DA (1983) Effects of in situ light reduction on density and growth of the seagrass Heterozostera tasmanica (Martens ex Aschers.) den Hartog in Western Port, Victoria, Australia. J Exp Mar Biol Ecol 67:91-103

Bulthuis DA, Brand GW, Mobley MC (1984) Suspended sediments and nutrients in water ebbing from seagrass-covered and denuded tidal mudflats in a southern Australian embayment. Aquat Bot 20:257-266

Cambridge ML, McComb AJ (1984) The loss of seagrasses in Cockburn Sound, western Australia. I. The time course and magnitude of seagrass decline in relation to industrial development. Aquat Bot 20:229-243

Dennison WC (1987) Effects of light on seagrass photosynthesis, growth and depth distribution. Aquat Bot 27: $15-26$

Duarte CM (1991) Seagrass depth limits. Aquat Bot 40: $363-377$

Duarte CM (1995) Submerged aquatic vegetation in relation to different nutrient regimes. Ophelia 41:87-112

Duarte CM, Terrados J, Agawin NSR, Fortes MD, Bach S, Kenworthy WJ (1997) Response of a mixed Philippine seagrass meadow to experimental burial. Mar Ecol Prog Ser 147:285-294

Fonseca MS, Fisher MS, Zieman JC, Thayer GW (1982) Influence of the seagrass, Zostera marina L., on current flow. Estuar Coast Shelf Sci 15:351-364

Fortes MD ( 1.988) Mangrove and seagrass beds of East Asia: habitats under stress. Ambio 17:207-213

Fortes MD (1995) Seagrasses of East Asia: environmental and management perspectives. RCU/EAS Technical report. Series No. 6. UNEP, Bangkok

Gordon DM, Grey KA, Chase SC, Simpson CJ (1994) Changes to the structure and productivity of a Posidonia sinuosa meadow during and after imposed shading. Aquat Bot 47:265-275

Kirk JTO (1983) Light and photosynthesis in aquatic ecosystems. Cambridge University Press, Cambridge

Madsen TV, Sand-Jensen K (1994) The interactive effects of light and inorganic carbon on aquatic plant growth. Plant Cell Environ 17:955-962

Malmer A. Grip H (1994) Converting tropical rainforest to forest plantation in Sabah. Malaysia. Part II. Effects on nutrient dynamics and net losses in streamwater Hydrol Proc 8:195-209

McManus LT, Cesar ZL, Guann FY (1990) Introduction. In: McManus LT, Thia-Eng $C$ (eds) The coastal environmen-

Editorial responsibility: Otto Kinne (Editor), Oldendorf/Luhe, Germany tal profile of the Lingayan Gulf. ICLARM Technical Reports, Manila, p 1-69

Milliman JD, Meade RH (1983) World-wide delivery of nver. sediments to the oceans. J Geol 91:1-21.

Milliman JD, Syvitski JPM (1992) Geomorphic/tectonic control of sediment discharge to the ocean: the importance of small mountainous rivers. J Geol 100:525-544

Olesen B (1996) Regulation of light attenuation and eelorass Zostera marina depth distribution in a Danish embayment. Mar Ecol Prog Ser 134:187-194

Onuf CP (1994) Seagrasses, dredging and light in Laguna Madre, Texas, U.S.A. Estuar Coast Shelf Sci 39:75-91

Orth RJ, Moore KA (1983) Chesapeake Bay: an unprecedented decline in submerged aquatic vegetation. Science 222:51-52

Parsons TR, Maita Y, Lalli CM (1984) A manual of chemical and biological methods for seawater analysis. Pergamon Press, Oxford

Sand-Jensen K, Borum J (1991) Interactions among phytoplankton, periphyton and macrophytes in temperate freshwaters and estuaries. Aquat Bot 41:137-175

Short FT, Wyllie-Echeverria S (1996) Natural and human induced disturbance of seagrasses. Environ Conserv 23: $17-27$

Smith RD, Pregnall AM, Alberte RS (1988) Effects of anaerobiosis on root metabolism of Zostera marina (eelgrass): implications for survival in reducing sediments. Mar Biol 98:131-141

Sokal R, Rohlf FJ (1995) Biometry. The principles and practice of statistics in biological research. WH Freeman and Company, New York

Terrados J, Duarte CM. Fortes MD, Borum J, Agawin NSR, Bach S, Thampanya U, Kamp-Nielsen L, Kenworthy WJ, Geertz-Hansen O, Vermaat JE (1998) Changes in community structure and biomass of seagrass communities along gradients of siltation in SE Asia. Estuar Coast Shelf Sci 46: $757-768$

Tomasko (1992) Variation in growth form of shoal grass (Halodule wrightii) due to changes in the spectral composition of light below a canopy of turtle grass (Thalassia tes(udinum). Estuaries 15:214-217

Vermaat JE, Agawin NSR, Duarte CM, Enriquez S, Fortes MD, Marbá N, Uri JS, van Vierssen W (1997) The capacity of seagrasses to survive increased turbidity and siltation: the significance of growth form and light use. Ambio 25: $499-504$

Vermaat JE, Agawin NSR, Duarte CM, Fortes MD, Marbá N, Uri JS (1995) Meadow maintenance, growth and productivity of a mixed Philippine seagrass bed. Mar Ecol Prog Ser 124:215-225

Williams SL (1987) Competition between the seagrasses Tha lassia testudinum and Syrngodium filiforme in a Caribbean lagoon. Mar Ecol Prog Ser 35:91-98

Ziemann JC, Fourqurean JW, Iverson RL (1989) Distrıbution, abundance and productivity of seagrasses and macroalgae in Florida Bay. Bull Mar Sci 44:292-311

Zieman JC, Wetzel RG (1980) Productivity in seagrasses. In: Phullips RC, McRoy CP (eds) A handbook of seagrass biology. Garland Press, New York, p 87-116

Submitted: May 18, 1998; Accepted: August 6, 1998

Proofs received from author(s): November 4, 1998 